\title{
LIX. Remarks on chemical changes of colour
}

\section{H.F. Talbot Esq. M.P. F.R.S.}

To cite this article: H.F. Talbot Esq. M.P. F.R.S. (1833) LIX. Remarks on chemical changes of colour, Philosophical Magazine Series 3, 2:11, 359-360, DOI: 10.1080/14786443308648057

To link to this article: http://dx.doi.org/10.1080/14786443308648057

册 Published online: 01 Jun 2009.

Submit your article to this journal $\pi$

Џll Article views: 2

Q View related articles $\sqsubset$ 
LIX. Remarks on Chemical Changes of Colour. By H. F. TALBOT, Esq. M.P. F.R.S.*

VERY little is known with certainty concerning the cause of those striking changes of colour which we so frequently witness in chemical experinents. No theory has yet been proposed which will by any means account for the whole of them, and we are often at a loss even for a plausible explanation. And yet these phænomena have probably some very close connexion with the ultimate constitution of bodies, and are therefore well worthy of our particular attention. I will therefore mention a few facts relating to this subject, hoping to engage others to pursue such inquiries further.

Water, being a colourless substance, ought, one would imagine, when mixed with other substances possessing no decided colour, to produce a colourless compound. Nevertheless it is to water only that the common vitriol or sulphate of copper owes its extremely vivid blueness; ns is plainly evinced by a simple experiment. For if we calcine the vitriol at a low red heat, and pulverize it, we shall obtain a powder of a dull and dirty white appearance. Now pour a little water upon this, and a slight hissing noise is heard, accompanied by an evolution of heat, very similar to what happens in the slaking of quick-lime. At the same moment the blue colour suddenly reappears. Mr. Faraday, to whom I showed this experiment, informed me it was new to him. I therefore presume it is a fact little, if at all known, and may interest your chemical readers.

Under the microscope this is a very pretty experiment, for the instant a drop of water is placed in contact with the vitriol, the amorphous powder is seen to shoot into blue prisms.

Are we then to infer that water has a tendency to communicate a blue rather than any other colour, to bodies in general? By no means; for in other instances its operation is exactly the reverse, and it is a destroyer instead of a promoter of blueness. For instance: sulphate of molybdenum is a liquid of a very rich dark blue, when sufficiently concentrated: but a very small portion of water suffices entirely to annihilate this blue tint, and to produce a mixture which is perfectly colourless. Thus the action of water upon the two metals copper and molybdenum is of an entirely opposite character. Instead of water if ammonia be used, the same contrast is seen still more strikingly. Another remarkable and well-known instance analogous to this is the muriate of cobalt, which is

* Communicated by the Author. 
entirely deprived of its fine blue colour by a very slight admixture of water.

Muriate of copper is described in most books of chemistry as a liquid of a bright green colour. But how imperfect an account of it this is, will be seen from the following experiment:-If sulphate of copper and muriate of lime (dry, or only slightly damp) be pulverized together in a mortar, muriate of copper is formed, of a dark yellow colour, or more frequently of a yellowish browon. If a few drops of water are now added, the yellow speedily changes to a bright green. If more water is added, the mixture becomes greenish blue, sky-blue, and finally colourless. If the water is evaporated by heat, the same colours reappear, in the reverse order*.

In Turner's Elements of Chemistry, it is said that nitric acid when containing a small portion of the orange nitrous gas, acquires a green tint; upon which he takes occasion to make the following remark (p. 193.):-

"It is difficult to perceive how an orange-coloured liquid should give different shades of green and blue merely by being diluted."

Now the above-mentioned property of muriate of copper seems to furnish an instance that is very analogous.

The mere application of heat often produces great change of colour, which disappears again when the substance becomes cold. Red lead, vermilion, and white oxide of zinc are instances well known, and never accounted for. Another curious example is furnished by the sulphate of molybdenum, which when warmed changes its fine blue tint to a pale yellow, again reverting to the blue when cold.

LX. Observations on the Alsorption of Specific Rays, in reference to the Undulatory Theory of Light. By Sir DAvid Brewster, LL.D. F.R.S. \&c.

$\mathrm{A}^{\mathrm{S}} \mathrm{Mr}$. Potter has referred in the last Number of this Journal light, I am anxious to state the views which $I$ have taken of this class of phænomena, in reference to the undulatory theory. I have long been an admirer of the singular power of this theory to explain some of the most perplexing phænomena of

* The yellow state of the muriate of copper is best exhibited by warming a sheet of paper on which letters have been written with it. The writing disappears again on cooling, because it absorbs the atmospheric moisture. The use of this salt as a sympathetic ink has been already mentioned by chemical writers. 